\title{
Impact of global warming on the distribution of Anastrepha grandis (Diptera: Tephritidae) in Brazil
}

\author{
Impacto potencial do aquecimento global sobre a distribuição \\ de Anastrepha grandis (Diptera: Tephritidae) no Brasil
}

\author{
Heitor Lisbôa' (D) (orcid.org/0000-0001-7527-1807) \\ Anderson Dionei Grutzmacher ${ }^{1}$ (D) (orcid.org/0000-0002-5464-9337) \\ Marcos Silveira Wrege ${ }^{2}$ (D) (orcid.org/0000-0002-6368-6586) \\ Flávio Roberto Mello Garcia' (1D) (orcid.org/0000-0003-0493-1788) \\ Dori Edson Nava ${ }^{3 *}$ (D) (orcid.org/0000-0002-4956-526X)
}

\begin{abstract}
Anastrepha grandis is one of the main pests related to Cucurbitaceae in South and Central America. This study discusses the impact of temperature increase on the number of generations of $A$. grandis, whose distribution could be aggravated due to temperature increase. Climatic variations were analyzed for reference scenarios obtained from 1961-1990 and of A2 and B1 climatic change scenarios of the Intergovernmental Panel on Climate Change, in which a less pessimistic scenario (B1) and a more pessimistic scenario (A2) were found. In relation to the reference scenarios, in colder seasons, the southern and southeastern regions are inadequate for the development of $A$. grandis, presenting one generation at most. In other regions of Brazil, where temperatures are higher throughout the year, the number of generations is at least two, and there is no variation from one climatic season to another. When analyzing the temperature increase, in a more pessimistic scenario (A2), there is a considerable variation in the number of generations, if we take into account three future climate scenarios in which $A$. grandis practically doubles the number of generations. In relation to a less pessimistic scenario (B1), there is a smaller variation in the number of generations, mainly in the southern region of the country. This variation is more accentuated in southeastern Brazil due to the temperature increase, in which the pest's number of generations doubles even in colder seasons.
\end{abstract}

KEYWORDS: abiotic factors; Cucurbitaceae; climatic changes; quarantine pest.
RESUMO: Anastrepha grandis é uma das principais pragas relacionadas à Cucurbitaceae nas Américas do Sul e Central. O presente trabalho teve como objetivo conhecer o impacto do aumento da temperatura no número de geraçôes de $A$. grandis, cuja distribuição poderá ser agravada devido ao aumento da temperatura. Essas variaçôes climatológicas foram analisadas para cenários de referência obtidos de 1961-1990 e nos cenários de mudanças climáticas A2 e B1 do Painel Intergovernamental de Mudanças Climáticas, onde encontramos um cenário menos pessimista (B1) e um mais pessimista (A2). Em relação ao período de referência é possível observar que, nas estaçóes mais frias, as regiōes Sul e Sudeste mostram-se inadequadas para o desenvolvimento de $A$. grandis, apresentando no máximo uma geração, enquanto nas estações mais quentes o inseto pode chegar a duas gerações. Nas demais regiôes do país, onde as temperaturas apresentam-se mais elevadas durante todo o ano, o número de gerações é de no mínimo duas e não há variação de uma estação climática para outra. Quando analisado o aumento da temperatura, em um cenário mais pessimista (A2), é possível observar uma variação considerável no número de gerações nos três cenários climáticos futuros, podendo $A$ grandis dobrar o número de geraçôes. Em relação a um cenário menos pessimista (B1), é evidente uma variação menor no número de gerações, principalmente na região Sul do país, enquanto que na região Sudeste essa variação já é mais acentuada devido ao aumento da temperatura, podendo dobrar o número de geraçôes mesmo nas estaçôes mais frias.

PALAVRAS-CHAVE: fatores abióticos; cucurbitáceas; mudanças climáticas; praga quarentenária.

\footnotetext{
'Universidade Federal de Pelotas - Capão do Leão (RS), Brazil.

${ }^{2}$ Embrapa Florestas - Colombo (PR), Brazil.

${ }^{3}$ Embrapa Clima Temperado - Pelotas (RS), Brazil.

*Corresponding author: dori.edson-nava@embrapa.br

Received on: 07/26/2018. Accepted on: 01/22/2020
} 


\section{INTRODUCTION}

The current phytosanitary scenario of Brazilian agriculture may be altered by anthropogenic climate change, influencing the importance of pests and diseases of cultivated plants. The analysis of the possible effects of climate change on the phytosanitary problems of commercial crops is key for the adoption of measures to mitigate damages (GHINI, 2005).

For insects in general, climate variables, especially air temperature, are important as they favor changes mainly in dispersal, development, and reproduction rates (WREGE et al., 2017). Temperature, humidity, and light are the abiotic factors that most affect fruit flies (GARCIA, 2009). Therefore, any changes in one of these components have a direct impact on the populations of insects.

Climate change affects insect species differently and should be studied in depth (KRÜGER et al., 2017). Some bioclimatic studies on fruit flies have been conducted to predict areas where pest species survive and reproduce (MESSENGER; FLITTERS, 1954). However, few studies investigate the impact of climate change on the development of agricultural pests under Brazilian conditions, mainly fruit flies.

The species Anastrepha fraterculus (Wiedmann, 1830), Anastrepha obliqua (Macquart), Anastrepha sororcula (Zucchi, 1979), A. grandis, and Ceratitis capitata (Wiedmann) are listed by the protection agencies of various countries as quarantine species (NASCIMENTO et al., 1993). In Brazil, the genera Ceratitis and Anastrepha are the most economically important, where the former is represented by only one species, Ceratitis capitata, while the latter is represented by 112 species (ZUCCHI, 2008). Both genera are responsible for considerable losses due to the frugivorous habit of their larvae, which cause damages to the fruit's mesocarp that make it unfit for consumption (DUARTE; MALAVASI, 2000). The importance of an insect species may vary depending on the host, region, or time of year within the same country (ZUCCHI, 2008).

Among the species of fruit flies with quarantine restrictions, we highlight $A$. grandis, whose main host are the Cucurbitaceae fruits, and is present in the southern, southeastern and central-western regions of Brazil. This species has oligophagous and multivoltine habits and is considered a quarantine pest of importance by cucurbit-importing countries (GARCIA, 2009). To export cucurbit fruits to countries that are free of this pest, countries where $A$. grandis is present must produce in pest free areas (PFA) or areas with the implementation of the integrated system for pest risk management (SPRM), which are programs recognized by official bodies (BOLZAN et al., 2016).

In southern Brazil, changes in the minimum air temperature have already been detected by studies of climate behavior in recent decades, as well as by time series analysis of climate data from state agricultural research institutions. Overall, the minimum temperature increase observed at various weather stations over the past 50 years has been of approximately $1.5^{\circ} \mathrm{C}$, varying according to location. An increase in the maximum temperature has also been detected, but to a lesser extent, about $0.5^{\circ} \mathrm{C}$ (RICCE et al., 2008; STEINMETZ et al., 2005).

Studies on insect population distribution indicate that rising temperatures may aggravate losses for crops. In this study, these increases were analyzed in the baseline climate-related scenarios obtained from 1961-1990 (HAMADA et al., 2008) and in the climate change scenarios A2 and B1 of the Intergovernmental Panel on Climate Change (IPCC) addressing the least pessimistic scenario (B1) and the most pessimistic scenario (A2) for the coming decades (MEEHL; STOCKER, 2007). This study investigated the impact of temperature increase on the number of generations of $A$. grandis in Brazil.

\section{MATERIAL AND METHODS}

The number of generations in a year was calculated by the total thermal sum existing at each location, dividing it by the thermal constant required for the completion of the insect's life cycle. This calculation was made for all regions of Brazil, using climate data organized by HAMADA et al. (2008), who verified the consistency, errors, and completeness of various climate models, selecting and compiling the best models, which were the models that best represented the reality of each region. The thermal sum was calculated for the base period of 1961-1990 (considered as reference period) and for projections of future climate scenarios until 2100.

The thermal sum was calculated by the difference between the average of the maximum and minimum temperatures and the lower developmental threshold temperature or base temperature $(\mathrm{Tb})$. The $\mathrm{Tb}$ represents the limit below which the insect does not develop because it does not find favorable conditions to complete its life cycle. Thus, in winter, the life cycle of the insect lasts longer than in summer, as the temperature often approaches the lower developmental threshold temperature in winter. Maps of the numbers of insect generations in the base period and projections of future scenarios were created by multiple linear regression, where the variable number of generations was correlated with altitude, latitude, and longitude of each location using the numerical model of the insect (MNT) of GTOPO30 (Table 1) (U.S. GEOLOGICAL SURVEY, 1999). The mappings were made in geographic information systems, using the ArcGIS 10 program. 


\section{RESULTS AND DISCUSSION}

Based on the thermal requirements obtained by BOLZAN et al. (2017) and the climatological norm of 1961-1990 (reference period), A. grandis can have one or two generations per year, possibly varying depending on region and climate season throughout the year (Tables 2 and 3) (Fig. 1). Comparing this baseline scenario with scenarios B1 (least pessimistic),

Table 1. Equations used to forecast the number of generations of Anastrepha grandis regarding altitude, latitude, and longitude for the reference period and future scenarios in different seasons.

\begin{tabular}{|c|c|c|c|}
\hline Scenario & Year season & Regression equation & $\mathbf{R}^{2}$ \\
\hline \multicolumn{4}{|c|}{ Reference period } \\
\hline Reference period & Spring & $2,476+0.018 *$ latitude $+0.0015 *$ longitude-0.0002*altitude & 0.68 \\
\hline Reference period & Summer & $2,364+0.006 *$ latitude $+0.0014 *$ Iongitude- $0.0003 *$ altitude & 0.60 \\
\hline Reference period & Fall & $2,478+0.025^{*}$ latitude+0.0016*longitude-0.0003*altitude & 0.76 \\
\hline Reference period & Winter & $2,445+0.034 *$ latitude $+0.0006 *$ longitude- $0.0002 *$ altitude & 0.79 \\
\hline \multicolumn{4}{|c|}{ Future scenarios with climate changes A2 and B 1 (2011-2040) } \\
\hline $2011-2040(A 2)$ & Spring & $2,476+0.018 *$ latitude $+0.0015 *$ longitude- $0.0002 *$ altitude & 0.68 \\
\hline $2011-2040(A 2)$ & Summer & $2,363+0.006 *$ latitude $+0.0014 *$ longitude-0.0003*altitude & 0.60 \\
\hline $2011-2040(\mathrm{~A} 2)$ & Fall & $2,480+0.026 *$ latitude $+0.0016 *$ longitude $-0.0003 *$ altitude & 0.80 \\
\hline $2011-2040(A 2)$ & Winter & $2,445+0.034 *$ latitude-0.0006*longitude-0.0002*altitude & 0.79 \\
\hline $2011-2040$ (B1) & Spring & $2,562+0.017 *$ latitude+0.0019*longitude-0.0002*altitude & 0.67 \\
\hline $2011-2040(B 1)$ & Summer & $2,440+0.006$ *latitude +0.0007 *longitude $-0.0003 *$ altitude & 0.63 \\
\hline $2011-2040(B 1)$ & Fall & $2,523+0.025 *$ latitude $+0.0006 *$ longitude $-0.0002 *$ altitude & 0.75 \\
\hline $2011-2040(B 1)$ & Winter & $2,451+0.033 *$ latitude-0.0009*longitude-0.0002*altitude & 0.79 \\
\hline \multicolumn{4}{|c|}{ Future scenarios with climate changes A2 and B1 (2041-2070) } \\
\hline $2041-2070(\mathrm{~A} 2)$ & Spring & $2,561+0.016^{*}$ latitude $+0.0007 *$ longitude $-0.0002 *$ altitude & 0.68 \\
\hline $2041-2070(\mathrm{~A} 2)$ & Summer & $2,485+0.006 *$ latitude $+0.0004 *$ longitude $-0.0002 *$ altitude & 0.65 \\
\hline $2041-2070(\mathrm{~A} 2)$ & Fall & $2,596+0.024 *$ latitude+0.0008*longitude-0.0002*altitude & 0.75 \\
\hline $2041-2070(\mathrm{~A} 2)$ & Winter & $2,472+0.032 *$ latitude-0.0015*longitude-0.0002*altitude & 0.79 \\
\hline $2041-2070(B 1)$ & Spring & $2,547+0.016 *$ latitude $+0.0012 *$ longitude $-0.0002 *$ altitude & 0.68 \\
\hline $2041-2070(B 1)$ & Summer & $2,449+0.006 *$ latitude $+0.0004 *$ longitude $-0.0003 *$ altitude & 0.64 \\
\hline $2041-2070(B 1)$ & Fall & $2,564+0.025 *$ latitude+0.0008*longitude-0.0002*altitude & 0.76 \\
\hline $2041-2070(B 1)$ & Winter & $2,453+0.032 *$ latitude-0.0011* Iongitude-0.0002*altitude & 0.79 \\
\hline \multicolumn{4}{|c|}{ Future scenarios with climate changes A2 and B1 (2071-2100) } \\
\hline $2071-2100(\mathrm{~A} 2)$ & Spring & $2,552+0.015 *$ latitude +0.0007 *longitude $-0.0002 *$ altitude & 0.68 \\
\hline $2071-2100(A 2)$ & Summer & $2,502+0.006 *$ latitude $+0.0003 *$ longitude $-0.0002 *$ altitude & 0.66 \\
\hline $2071-2100(\mathrm{~A} 2)$ & Fall & $2,609+0.022 *$ latitude+0.0012*longitude-0.0002*altitude & 0.75 \\
\hline $2071-2100(A 2)$ & Winter & 2,493+0.032*latitude-0.0009*longitude-0.0001*altitude & 0.78 \\
\hline $2071-2100(B 1)$ & Spring & $2,561+0.016 *$ latitude+0.0008*longitude-0.0002*altitude & 0.68 \\
\hline $2071-2100(B 1)$ & Summer & $2,485+0.006 *$ latitude $+0.0004 *$ longitude $-0.0002 *$ altitude & 0.66 \\
\hline $2071-2100(B 1)$ & Fall & $2,587+0.045 *$ latitude+0.0007*longitude-0.0002*altitude & 0.76 \\
\hline $2071-2100(B 1)$ & Winter & $2,465+0.032 *$ latitude-0.0016*longitude-0.0002*altitude & 0.80 \\
\hline
\end{tabular}


A2 (most pessimistic) with high GHG emissions (Fig. 2), and with low GHG emissions (Fig. 3), there is an increase in the number generations, especially in the colder seasons of the year, as temperatures tend to increase over the years.

The best development of $A$. grandis occurs in warmer regions, usually with lower altitudes. In higher altitude zones, where temperatures are lower, dissemination is slower (Fig. 1). Taking this definition into account, the most pessimistic scenario A2 is characterized by the maintenance of GHG emission standards observed in recent decades, which would imply higher atmospheric concentrations. On the other hand, scenario B1 would have lower GHG emissions, or a least pessimistic scenario, with a tendency towards stabilization of GHG emissions and concentration at the end of this century, at about $550 \mathrm{ppm}$ (NAKIĆENOVIĆ et al., 2000).

The South American cucurbit fly, as well as all flies belonging to the genera Anastrepha, Ceratitis and Dacus, are multivoltine with more than one generation a year, without diapause, and distributed in tropical regions (BATEMAN, 1972; GARCIA, 2009). Although development in alternative hosts is reduced, insects can survive unfavorable seasons and later, in a next generation, attack their preferred hosts.

Table 2. Locations with Anastrepha grandis, pest free area, risk mitigation system area and number of generations, reference period, and projections for the most pessimistic scenario (A2), in different seasons in Brazil.

\begin{tabular}{|c|c|c|c|c|c|c|c|c|c|c|c|c|c|c|c|c|c|c|}
\hline \multirow[b]{2}{*}{ State } & \multirow[b]{2}{*}{ Location } & \multirow[b]{2}{*}{ Status } & \multicolumn{4}{|c|}{$\begin{array}{l}\text { No. of generations } \\
\text { (Reference period) }\end{array}$} & \multicolumn{4}{|c|}{$\begin{array}{l}\text { No. of generations } \\
2011-2040 \text { (A2) }\end{array}$} & \multicolumn{4}{|c|}{$\begin{array}{l}\text { No. of generations } \\
2041-2070 \text { (A2) }\end{array}$} & \multicolumn{4}{|c|}{$\begin{array}{l}\text { No. of generations } \\
2071-2100 \text { (A2) }\end{array}$} \\
\hline & & & 을 & 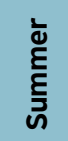 & $\overline{\bar{\varpi}}$ & 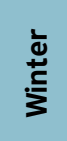 & 号 & 㐫 & $\overline{\bar{\varpi}}$ & $\stackrel{\frac{1}{ \pm}}{\stackrel{c}{c}}$ & 竞 & $\begin{array}{l}\frac{\text { ¿ }}{\text { हू }} \\
\text { जे }\end{array}$ & $\overline{\bar{\varpi}}$ & 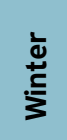 & $\begin{array}{l}\text { 믄 } \\
\text { ம் }\end{array}$ & ڤั & $\overline{\bar{\pi}}$ & $\frac{\grave{s}}{\stackrel{ \pm}{c}}$ \\
\hline RN & Mossoró & PFA-MF & 2.2 & 2.2 & 2.2 & 2.2 & 2.2 & 2.2 & 2.2 & 2.2 & 2.4 & 2.4 & & 2.2 & 2.2 & 2.2 & 2.4 & 2.2 \\
\hline $\mathrm{RN}$ & Assu & PFA-MF & 2.2 & 2.2 & 2.2 & 2.2 & 2.2 & 2.2 & 2.2 & 2.2 & 2.4 & 2.4 & 2.3 & 2.2 & 2.2 & 2.2 & 2.4 & 2.2 \\
\hline $\mathrm{RN}$ & Macau & SPRM & 2.2 & 2.2 & 2.2 & 2.2 & 2.2 & 2.2 & 2.2 & 2.2 & 2.4 & 2.4 & 2.3 & 2.2 & 2.2 & 2.2 & 2.4 & 2.2 \\
\hline $\mathrm{RN}$ & Jandaíra & SPRM & 2.2 & 2.2 & 2.2 & 2.2 & 2.2 & & 2.2 & 2.2 & 2.4 & 2.4 & & 2.2 & 2.2 & 2.2 & 2.4 & 2.2 \\
\hline CE & Jaguaruana & PFA-MF & 2.2 & 2.2 & 2.2 & 2.2 & 2.2 & 2.2 & 2.2 & 2.2 & 2.4 & 2.4 & 2.4 & 2.2 & 2.2 & 2.4 & 2.4 & 2.2 \\
\hline BA & Curaçá & Occurrence & 2.0 & 2.0 & 2.0 & 1.8 & 2.0 & 2.0 & 1.7 & 1.7 & 1.9 & 1.9 & 1.9 & 1.9 & 1.8 & 1.8 & 2.2 & 2.2 \\
\hline MT & Rondonópolis & Occurrence & 2.0 & 2.0 & 1.7 & 1.5 & 1.7 & 2.0 & 1.7 & 1.9 & 1.8 & 1.8 & 2.0 & 2.0 & 1.6 & 1.6 & 2.2 & 2.2 \\
\hline GO & Goianésia & SPRM & 2.0 & 2.0 & & 1.6 & 1.9 & 2.0 & 1.9 & 1.9 & 2.1 & 1.8 & 1.8 & 2.1 & 1.8 & 1.9 & 2.1 & 2.1 \\
\hline RJ & Nova Iguaçu & Occurrence & 2.0 & 2.0 & & 1.3 & 1.6 & & & 1.9 & 1.8 & & 1.8 & 2.1 & 1.6 & 1.6 & 2.0 & 2.0 \\
\hline RJ & Seropédica & Occurrence & 2.0 & 2.0 & 1.6 & 1.3 & 1.6 & 1.9 & 1.6 & 1.9 & 1.8 & 1.6 & 1.8 & 2.1 & 1.6 & 1.6 & 2.0 & 2.0 \\
\hline SP & $\begin{array}{l}\text { Presid. } \\
\text { Prudente }\end{array}$ & Occurrence & 1.7 & 1.7 & 1.4 & 1.4 & 1.5 & 1.7 & 1.4 & 1.6 & 1.7 & 1.6 & 1.8 & 1.9 & 1.6 & 1.6 & 1.9 & 1.8 \\
\hline SP & Mesópolis & SPRM & 1.7 & 1.7 & 1.4 & 1.4 & 1.5 & & 1.4 & 1.6 & 1.7 & 1.6 & 1.8 & 1.9 & 1.6 & 1.6 & 1.9 & 1.8 \\
\hline SP & & & 1.7 & & 1.4 & 1.4 & 1.5 & & 1.4 & 1.6 & 1.7 & 1.6 & 1.8 & 1.9 & 1.6 & 1.6 & 1.9 & 1.8 \\
\hline SP & $\begin{array}{c}\text { Presid. } \\
\text { Bernardes }\end{array}$ & SPRM & 1.7 & 1.7 & 1.4 & 1.4 & 1.5 & 1.7 & 1.4 & 1.6 & 1.7 & 1.6 & 1.8 & 1.9 & 1.6 & 1.6 & 1.9 & 1.8 \\
\hline SP & Paranapuã & & & 1.7 & 1.4 & & 1.5 & & 1.4 & 1.6 & 1.7 & & 1.8 & 1.9 & 1.6 & 1.6 & 1.9 & 1.8 \\
\hline PR & Maringá & Occurrence & 1.6 & 1.6 & 1.2 & 1.1 & 1.3 & 1.7 & 1.4 & 1.4 & 1.6 & 1.7 & 1.8 & 1.6 & 1.5 & 1.5 & 1.8 & 1.8 \\
\hline PR & $\begin{array}{l}\text { Sta Isabel } \\
\text { do Ivaí }\end{array}$ & SPRM & 1.6 & 1.6 & 1.2 & 1.1 & 1.3 & 1.7 & 1.4 & 1.4 & 1.6 & 1.7 & 1.8 & 1.6 & 1.5 & 1.5 & 1.8 & 1.8 \\
\hline SC & Lages & Occurrence & 1.4 & 1.4 & 1.2 & 1.1 & 1.2 & 1.4 & 1.2 & 1.4 & 1.4 & 1.3 & 1.6 & 1.8 & 1.4 & 1.4 & 1.8 & 1.8 \\
\hline RS & Montenegro & Occurrence & 1.6 & 2.0 & 1.2 & 1.1 & 1.2 & 1.4 & 1.5 & 1.9 & 1.4 & 1.3 & 1.7 & 1.9 & 1.4 & 1.4 & 1.8 & 1.8 \\
\hline RS & Bagé & SPRM & 1.4 & 1.7 & 1.2 & 1.1 & 1.2 & 1.4 & 1.1 & 1.7 & 1.4 & 1.3 & 1.6 & 1.8 & 1.4 & 1.4 & 1.8 & 1.8 \\
\hline
\end{tabular}

SPRM: system for pest risk management; PFA-FF: pest free area-fruit flies. 
At present, considering the average, $A$. grandis can have two generations per year in the most development-friendly regions of northeastern and southeastern Brazil (Fig. 2). This number may be higher with increasing temperatures, rising from one to nearly two generations per year in colder, higher altitude regions, and at most three generations per year in warmer, lower altitude regions. This means doubling the number of generations compared to the reference period. For future projections, in scenario B1, there is an increase of only one generation per year, either in the warmer, lower altitude regions, or in the colder, higher altitude regions (Fig. 3).
Research on pest management techniques and actions to mitigate the effects of climate change is strategic, seeking at least to maintain the insect population at current levels and thus avoiding further contamination of the environment by use of pesticides, as well as their effect on plant toxicity. Thus, zoning based on climatic factors that influence insect development allows the definition of ecologically favorable and/ or unfavorable environments for its development (BAKER et al., 2000). Climate change can also affect insects indirectly, induced by other factors, namely, interaction with another species (competition, predation, and parasitism) or interaction with host plants for herbivorous insects. Global warming can

Table 3. Sites with occurrence of Anastrepha grandis, pest free area, risk mitigation system area, and number of generations, reference period and projections for the least pessimistic scenario (B1), in different seasons in Brazil.

\begin{tabular}{|c|c|c|c|c|c|c|c|c|c|c|c|c|c|c|c|c|c|c|}
\hline \multirow[b]{2}{*}{ State } & \multirow[b]{2}{*}{ Location } & \multirow[b]{2}{*}{ Status } & \multicolumn{4}{|c|}{$\begin{array}{l}\text { No. of generations } \\
\text { (Reference period) }\end{array}$} & \multicolumn{4}{|c|}{$\begin{array}{l}\text { No. of generations } \\
2011-2040 \text { (A2) }\end{array}$} & \multicolumn{4}{|c|}{$\begin{array}{l}\text { No. of generations } \\
2041-2070(A 2)\end{array}$} & \multicolumn{4}{|c|}{$\begin{array}{l}\text { No. of generations } \\
2071-2100(A 2)\end{array}$} \\
\hline & & & 容 & 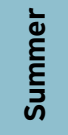 & $\overline{\bar{\varpi}}$ & & 容 & $\begin{array}{l}\text { ¿̀ } \\
\text { है } \\
\text { ڤ }\end{array}$ & $\overline{\overline{\varpi 0}}$ & 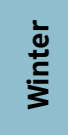 & 은 & 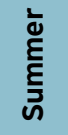 & $\overline{\bar{\pi}}$ & 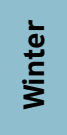 & 总 & 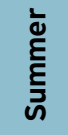 & $\overline{\bar{\varpi}}$ & \\
\hline $\mathrm{RN}$ & Mossoró & PFA-MF & 2.2 & 2.2 & 2.2 & 2.2 & 2.2 & 2.2 & 2.4 & 2.2 & 2.1 & 2.1 & 2.4 & 2.4 & 2.4 & 2.2 & 2.4 & 2.2 \\
\hline RN & Assu & PFA-MF & 2.2 & 2.2 & 2.2 & 2.2 & 2.2 & 2.2 & 2.4 & 2.2 & 2.1 & 2.1 & 2.4 & 2.4 & 2.4 & 2.2 & 2.4 & 2.2 \\
\hline RN & Macau & SPRM & 2.2 & 2.2 & 2.2 & 2.2 & 2.2 & 2.2 & 2.4 & 2.2 & 2.1 & 2.1 & 2.4 & 2.4 & 2.4 & 2.2 & 2.4 & 2.2 \\
\hline RN & Jandaíra & SPRM & 2.2 & 2.2 & 2.2 & 2.2 & 2.2 & 2.2 & & 2.2 & 2.1 & 2.1 & 2.4 & & 2.4 & 2.2 & 2.4 & 2.2 \\
\hline CE & Jaguaruana & PFA-MF & 2.2 & 2.2 & 2.2 & 2.2 & 2.2 & 2.2 & 2.4 & 2.2 & 2.4 & 2.2 & 2.4 & 2.4 & 2.4 & 2.4 & 2.4 & 2.4 \\
\hline BA & Curaçá & Occurrence & 2.0 & 2.0 & 2.0 & 1.8 & 2.2 & 1.7 & 1.9 & 1.9 & 1.8 & 1.8 & 2.1 & 1.9 & 1.8 & 1.8 & 2.2 & 2.2 \\
\hline MT & Rondonópolis & Occurrence & 2.0 & 2.0 & 1.7 & 1.5 & 2.2 & 1.6 & 1.8 & 1.8 & 1.6 & 1.5 & 1.8 & 1.9 & 1.7 & 1.7 & 2.2 & 2.0 \\
\hline GO & Goianésia & SPRM & 2.0 & 2.0 & 1.9 & 1.6 & 2.2 & 1.9 & 1.9 & 1.9 & 1.8 & 1.8 & 2.0 & 2.0 & 1.9 & 1.9 & 2.0 & 2.0 \\
\hline RJ & Nova Iguaçu & Occurrence & 2.0 & 2.0 & 1.6 & 1.3 & 2.2 & 1.6 & 1.8 & 2.0 & 1.5 & 1.5 & 1.7 & 1.7 & 1.7 & 1.5 & 1.7 & 1.7 \\
\hline RJ & Seropédica & Occurrence & 2.0 & 2.0 & 1.6 & 1.3 & 2.2 & 1.6 & 1.8 & 2.0 & 1.5 & 1.5 & 1.7 & 1.7 & 1.7 & 1.5 & 1.7 & 1.7 \\
\hline SP & $\begin{array}{l}\text { Presid. } \\
\text { Prudente }\end{array}$ & Occurrence & 1.7 & 1.7 & 1.4 & 1.4 & 2.2 & 1.6 & 1.8 & 1.8 & 1.6 & 1.6 & 1.7 & 1.8 & 1.6 & 1.6 & 1.7 & 1.9 \\
\hline SP & Mesópolis & & 1.7 & & 1.4 & 1.4 & 22 & 1.6 & & 1.8 & 1.6 & 1.6 & 1.7 & & 1.6 & 1.6 & 1.7 & 1.9 \\
\hline SP & Urânia & SPRM & 1.7 & & 1.4 & 1.4 & 2.2 & 1.6 & 1.8 & 1.8 & 1.6 & 1.6 & 1.7 & 1.8 & 1.6 & 1.6 & 1.7 & 1.9 \\
\hline SP & $\begin{array}{l}\text { Presid. } \\
\text { Bernardes }\end{array}$ & SPRM & 1.7 & 1.7 & 1.4 & 1.4 & 2.2 & 1.6 & 1.8 & 1.8 & 1.6 & 1.6 & 1.7 & 1.8 & 1.6 & 1.6 & 1.7 & 1.9 \\
\hline SP & Paranapuã & & 1.7 & & 1.4 & 1.4 & 2.2 & 1.6 & 1.8 & 1.8 & 1.6 & 1.6 & 1.7 & 1.8 & 1.6 & 1.6 & 1.7 & 1.9 \\
\hline PR & Maringá & Occurrence & 1.6 & 1.6 & & & 2.2 & 1.2 & & 1.5 & 1.3 & & 1.6 & & 1.4 & 1.4 & 1.6 & 1.6 \\
\hline PR & $\begin{array}{l}\text { Sta Isabel } \\
\text { do Ivaí }\end{array}$ & SPRM & 1.6 & 1.6 & 1.2 & 1.1 & 2.2 & 1.2 & 1.5 & 1.5 & 1.3 & 1.3 & 1.6 & 1.6 & 1.4 & 1.4 & 1.6 & 1.6 \\
\hline SC & Lages & Occurrence & 1.4 & & 1.2 & 1.1 & 2.2 & 1.1 & 1.5 & 1.5 & 1.3 & 1.3 & 1.6 & 1.6 & 1.4 & 1.3 & 1.6 & 1.6 \\
\hline RS & Montenegro & Occurrence & 1.6 & 2.0 & 1.2 & 1.1 & 2.2 & 1.1 & 1.5 & 1.8 & 1.5 & 1.3 & 1.7 & 1.7 & 1.4 & 1.3 & 1.7 & 1.7 \\
\hline RS & Bagé & SPRM & 1.4 & 1.7 & 1.2 & 1.1 & 2.2 & 1.1 & 1,5 & 1.8 & 1.3 & 1.3 & 1.6 & 1.7 & 1.4 & 1.3 & 1.6 & 1.7 \\
\hline
\end{tabular}

SPRM: system for pest risk management; PFA-FF: pest free area-fruit flies. 
affect the structure of existing communities because individual responses will inevitably alter interactions between insect species and lead to changes in the composition of natural communities (MENÉNDEZ, 2007).

Temperature, precipitation, humidity, and other climatic parameters affect several insect biological activities (rates of development, reproduction, distribution, migration, and adaptation). In addition, indirect effects may occur through the influence of climate on host plants, natural enemies, and interspecific interactions with other insects. Thus, climate change resulting from increased GHG emissions in the atmosphere could have a significant impact on the development, distribution, and population density of natural insect pests (PORTER et al., 1991).

Considering areas free of $A$. grandis, in the states of Ceará and Rio Grande do Norte, the environmental conditions and vegetation type of the semi-arid do not favor the permanence of high population densities of fruit flies throughout the year, and the number of flies caught during the driest months of the year is very limited (ARAÚJO et al., 2000).

Future projections were based on the needs of $A$. grandis regarding environmental factors (temperature and relative humidity). Based on the analysis of these factors, future climatic conditions are favorable to the development of this pest. SANTOS (2008) described that $A$. fraterculus and $C$. capitata could adapt to the temperature increase predicted for 2080. However, in the case of frugivorous species, it is also necessary to consider that the natural conditions favorable to maintaining their host plants are crucial to the survival of fruit flies, regardless of the intrinsic biological characteristics of these insects, as well as the effect of the natural conditions on their natural enemies (KRÜGER et al., 2017).

\section{CONCLUSIONS}

- Projections for 2041 to 2070 point to a tendency of increase in air temperature, thus favoring the spread of A. grandis population, with an increase in the number of generations that occur in a year.

- At present, the number of $A$. grandis generations can be higher with increasing temperatures, from one to nearly two generations a year in colder regions and up to three generations a year in warmer regions.

- Future projections point to an increase of one generation per year in both warmer and colder regions.
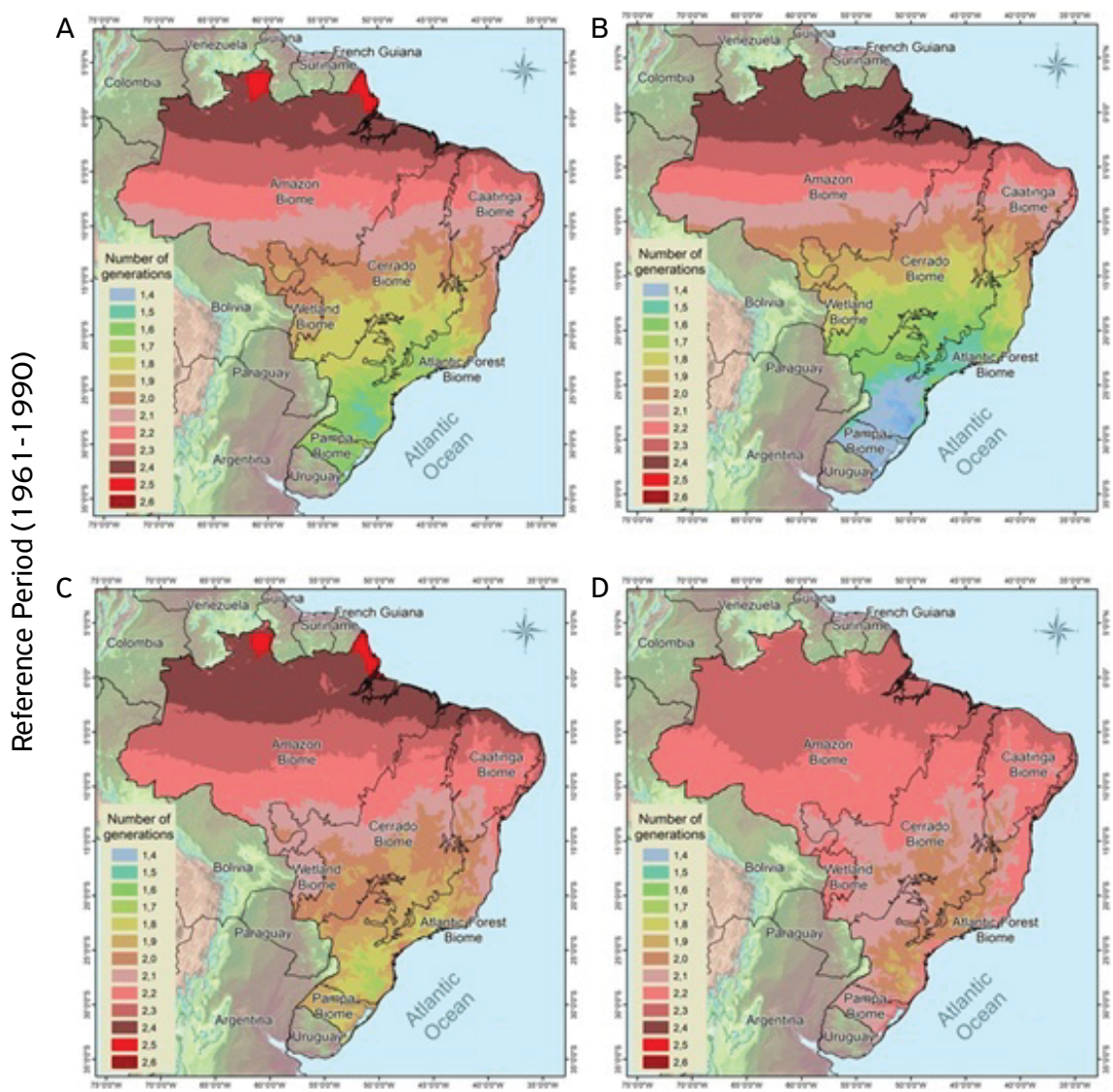

Figure 1. Climatic maps of Brazil, reference period 1961-1990, where (A) fall, (B) winter, (C) spring, and (D) summer. 


\section{Future climatic scenario from 2011-2040 A2}
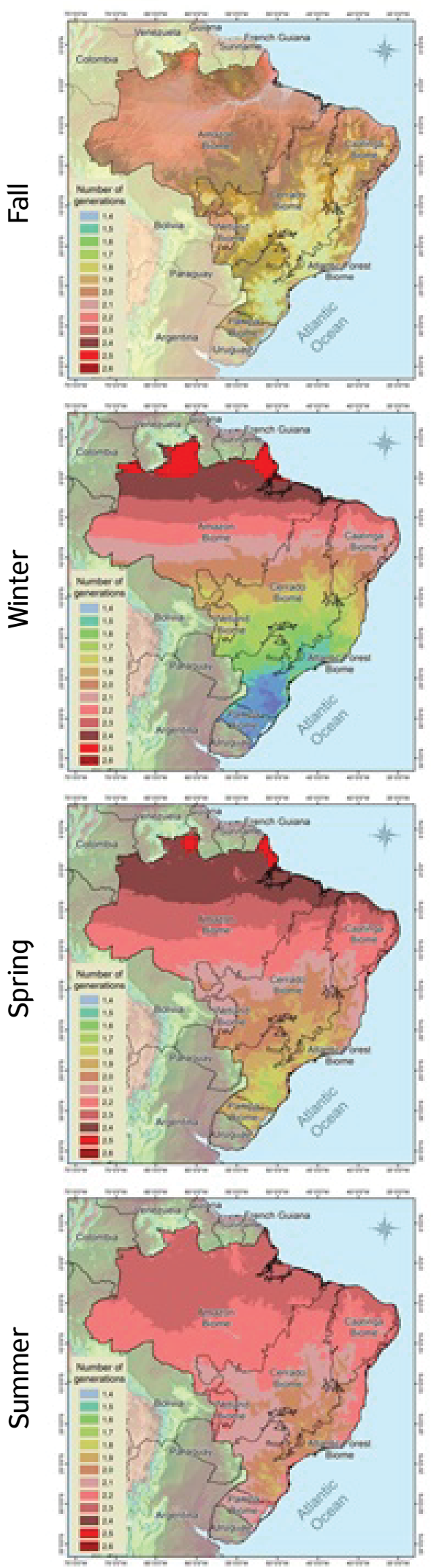

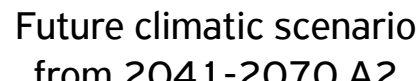

from 2041-2070 A2
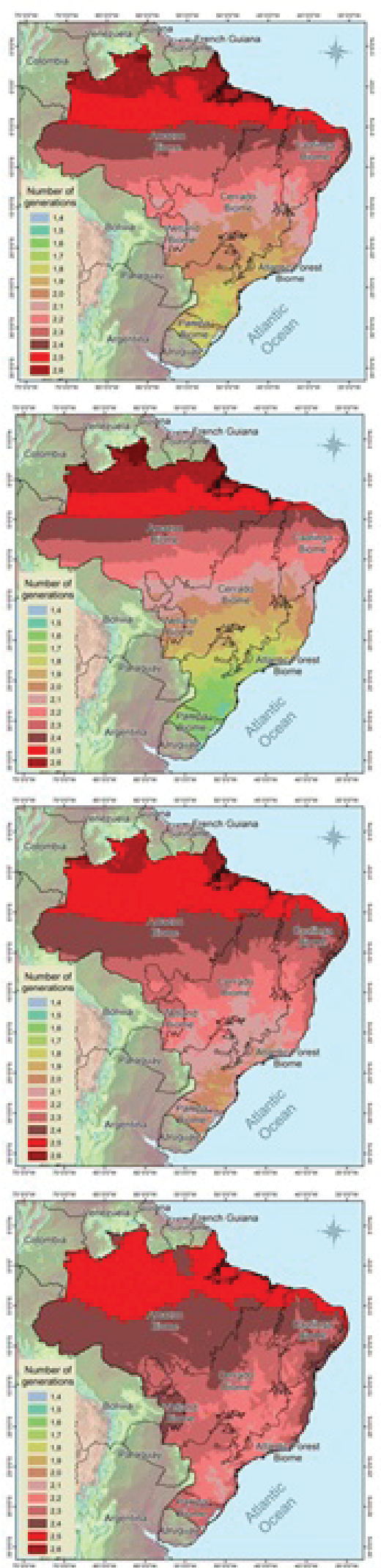

\section{Future climatic scenario from 2071-2100 A2}
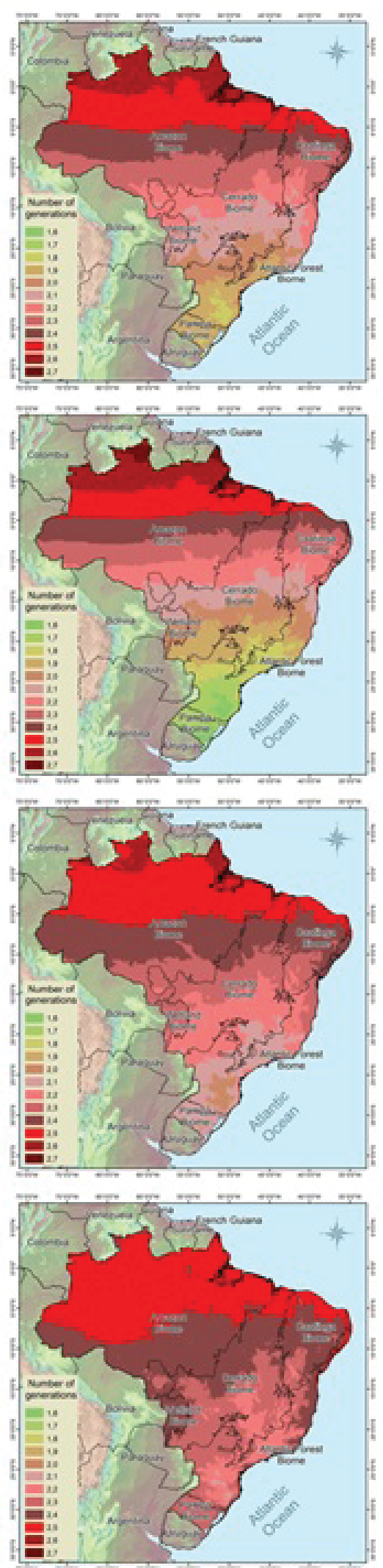

Figure 2. Generations of Anastrepha grandis per year in Brazil in different year seasons, in the most pessimistic climate change scenario (A2), in projections for 2011-2040, 2041-2070 and 2071-2100. 

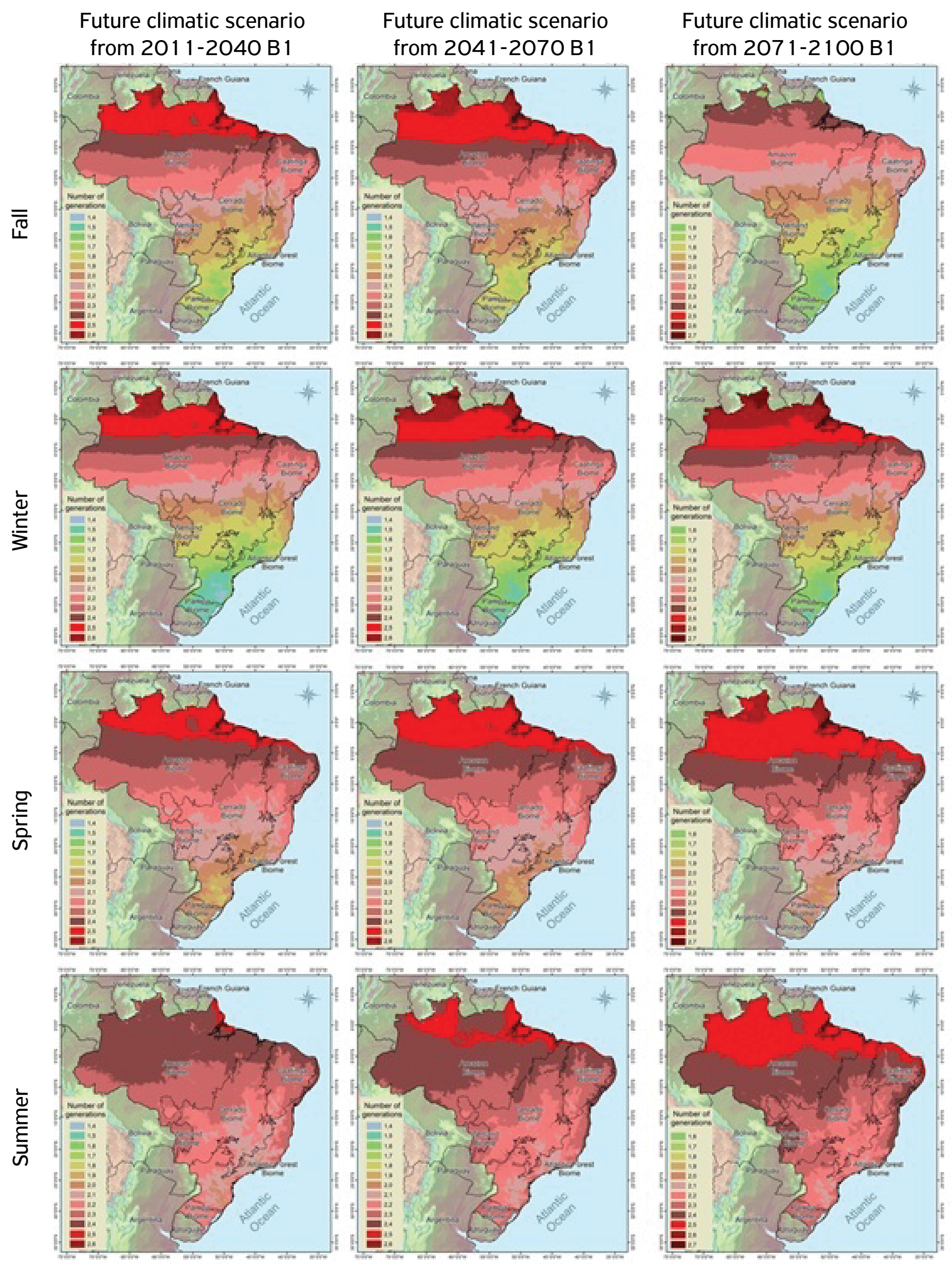

Figure 3. Generations of Anastrepha grandis per year in Brazil in different year seasons, in the least pessimistic climate change scenario (B1), in projections for 2011-2040, 2041-2070 and 2071-2100. 
- In the northeastern region of Brazil, where areas free of A. grandis are located, populations of fruit fly are considerably smaller than in the coastal regions, mainly due to the climatic conditions and vegetation type of the semiarid region, which do not favor high densities of the pest throughout the year.

ACKNOWLEDGEMENTS: Not applicable.

FUNDING: This study was financed in part by the Coordenação de Aperfeiçoamento de Pessoal de Nível Superior - Brasil

(CAPES) - Finance Code 001.

CONFLICTS OF INTEREST: All authors declare that they have no conflict of interest.

ETHICAL APPROVAL: Not applicable.

AVAILABILITY OF DATA AND MATERIAL: The datasets generated and/or analyzed during the current study are available from the corresponding author on reasonable request.

AUTHORS' CONTRIBUTIONS: Conceptualization, Methodology, Investigation, Formal analysis, Visualization, Writing - Original draft: Lisbôa, H. Conceptualization, Methodology: Grutzmacher, A.D. Investigation, Formal analysis, Writing review \& editing: Wrege, M.S. Writing - review \& editing: Garcia, F. R. M. Conceptualization, Writing - Review \& Editing, Resource, Funding acquisition: Nava, D. E.

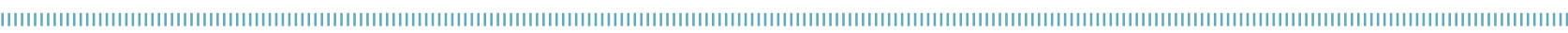

\section{REFERENCES}

ARAÚJO, E.L.; LIMA, F.A.M.; ZUCCHI, R.A. Rio Grande do Norte. In: MALAVASI, A.; ZUCCHI, R.A. (Ed.). Moscas-das-frutas de importância econômica no Brasil - Conhecimento básico e aplicado. Ribeirão Preto: Holos, 2000. p.223-228.

BAKER, R.H.A.; SANSFORD, C.E.; JARVIS, C.H.; CANNON, R.J.C.; MCLEOD, A.; WALTERS, K.F.A. The role of climatic mapping in predicting the potential geographical distribution of nonindigenous pests under current and future climates. Agriculture, Ecosystems and Environment, v.82, n. 1-3, p.57-71, 2000. https:// doi.org/10.1016/S0167-8809(00)00216-4

BATEMAN, M.A. The ecology of fruit flies. Annual Review of Entomology, Palo Alto, v.17, p.493-518, 1972. https://doi. org/10.1146/annurev.en.17.010172.002425

BOLZAN, A.; DIEZ-RODRIGUEZ, G.I.; GARCIA, F.R.M.; NAVA, D.E. Anastrepha grandis: bioecologia e manejo. Pelotas: Embrapa Clima Temperado, 2016. 24 p. (Embrapa Clima Temperado, Documentos, 404).

BOLZAN, A.; NAVA, D.E.; SMANIOTTO, G.; VALGAS, R.A.; GARCIA, F.R.M. Development of Anastrepha grandis (Diptera: Tephritidae) under constant temperatures and field validation of a laboratory model for temperature requirements. Crop Protection, v.100, p.38-44, 2017. https://doi.org/10.1016/j.cropro.2017.06.001

DUARTE, A.L.; MALAVASI, A. Tratamentos quarentenários. In: MALAVASI, A.; ZUCCHI, R.A. Moscas-das-frutas de importância econômica no Brasil - Conhecimento básico e aplicado. Ribeirão Preto: Holos Editora, 2000. p. 187-192.
GARCIA, F.R.M. Fruit fly: biological and ecological aspects. In: BANDEIRA, R.R. (Ed.). Current trends in fruit flies control on perennial crops and research prospects. Kerala: Transworld Research Network, 2009. p. 1-35.

GHINI, R. Mudanças climáticas globais e doenças de plantas. Jaguariúna: Embrapa Meio Ambiente, 2005. 104p.

HAMADA, E.; GONÇALVES, R.R.V.; MARENGO, J.A.; GHINI, R. Cenários climáticos futuros para o Brasil. In: GHINI, R.; HAMADA, E. (Org.). Mudanças climáticas: impactos sobre doenças de plantas no Brasil. Brasília: Embrapa Informação Tecnológica, 2008. p. 25-73.

KRÜGER, A.P.; PIOVESAN, B.; PETER, R.; SCHEUNEMANN, T.; GARCIA, F.R.M. Mudanças climáticas podem afetar o controle biológico de pragas? O Biológico, v.79, n.1, p.1-7, 2017.

MEEHL, G.A.; STOCKER, T.F. Global climate projections. In: SOLOMON, S.D; QIN, M.; MANNING, Z.; CHEN, M.; MARQUIS, K.B.; AVERYT, M.; TIGNOR; MILLER, H.L. (Ed.). Climate Change 2007: the physical science basis: contribution of Working Group I to the Fourth Assessment Report of the Intergovernmental Panel on Climate Change. Cambridge: Cambridge University Press, 2007. p. 747-845.

MENÉNDEZ, R. How are insects responding to global warming? Tijdschrift voor Entomologie, v.150, p.355-365, 2007.

MESSENGER, P.S.; FLITTERS, N.E. Bioclimatic studies of three species of fruit flies in Hawaii. Journal of Economic Entomology, v.47, n.5, p.756-765, 1954. https://doi.org/10.1093/ jee/47.5.756 
NAKIĆENOVIĆ, N.; DAVIDSON, O.; DAVIS, G.; GRUBLER, A.; KRAM, T.; LA ROVERE, E.L.; METZ, B.; MORITA, T.; PEPPER, W.; PITCHER, H.; SANKOVSKI, A.; SHUKLA, P.; SWART, R.; WATSON, R.; DADI, Z. Emissions scenarios. Cambridge University Press, 2000. (IPCC Special Reports). Available from: http://pure.iiasa.ac.at/6101/2/ sres-en.pdf. Access on: May 082018.

NASCIMENTO, A.S.; MORGANTE, J.S.; MALAVASI, A.; URAMOTO, K. Ocurence and distribution of Anastrepha in melon production areas in Brazil. In: ALUJA, M.; LIEDO, P. (Ed.). Fruit flies: biology and management. New York: Springer-Verlag, 1993. p.39-42.

PORTER, J.H.; PARRY, M.L.; CARTER, T.R. The potential effects of climatic change on agricultural insect pests. Agricultural and Forest Meteorology, v.57, n.1-3, p.221-240, 1991. https://doi. org/10.1016/0168-1923(91)90088-8

RICCE, W.S.; CARAMORI, P.H.; CAVIGLIONE, J.H.; MORAIS, H.; PEREIRA, L.M.P. Estudo das temperaturas mínimas e máximas no Estado do Paraná. In: SIMPÓSIO BRASILEIRO DE CLIMATOLOGIA GEOGRÁFICA, 8., 2008, Alto Caparaó. Anais... Uberlândia: UFU, 2008. p. 200-210.

SANTOS, W.S. Zoneamento ecológico de Anastrepha fraterculus e Ceratitis capitata (Diptera: Tephritidae) em dois cenários climáticos no Brasil. 96p. Thesis (PhD degree) - Escola Superior de Agricultura Luiz de Queiroz, Piracicaba, 2008. https://doi. org/10.1 1606/T.1 1.2008.tde-12062008-161926
STEINMETZ, S.; SIQUEIRA, O.J.W.; WREGE, M.S.; HERTER, F.G.; REISSER JÚNIOR, C. Aumento da temperatura mínima do ar na região de Pelotas, sua relação com o aquecimento global e possíveis consequências para o arroz irrigado no Rio Grande do Sul. In: CONGRESSO BRASILEIRO DE AGROMETEOROLOGIA, 14., Campinas. Anais... Campinas: Sociedade Brasileira de Agrometeorologia, 2005. 1 CD-ROM.

U.S. GEOLOGICAL SURVEY. Survey National Mapping Division: Global 30 Arc Second Elevation Data. 1999. Available from: https://www.usgs.gov/centers/eros/science/usgs-eros-archivedigital-elevation-global-30-arc-second-elevation-gtopo30. Access on: Mar. 302018.

WEBER, E.; HASENACK, H.; FERREIRA, C.J.S. Adaptação do modelo digital de elevação do SRTM para o sistema de referência oficial brasileiro e recorte por unidade da federação. Porto Alegre: UFRGS, 2004. Available from: www.lea.esalq.usp.br/anastrepha/. Access on: Apr. 102018.

WREGE, M.S.; BARBOSA, L.R.; AUER, C.G.; SANTOS, A.F. Influência das mudanças climáticas nas zonas de ocorrência do percevejobronzeado do eucalipto. In: BETTIOL, W.; HAMADA, E.; ANGELOTTI, F.; AUAD, A.M.; GHINI, R. (Eds.). Aquecimento global e problemas fitossanitários. Brasília: Embrapa, 2017. p.440-452.

ZUCCHI, R.A. Fruit flies in Brazil - Anastrepha species their host plants and parasitoids. 2008. Available from: www.lea.esalq.usp. br/anastrepha/. Access on: Apr. 102018. 